\title{
"ESPETÁCULOS DE RUA": MANIFESTAÇÕES CULTURAIS NO LARGO GLÊNIO PERES E NO BRIQUE DA REDENÇÃO NA CIDADE DE PORTO ALEGRE/RS ${ }^{1}$
}

\author{
Neiva Rosa Garcia ${ }^{2}$
}

\section{Introdução}

Porto Alegre é privilegiada no que diz respeito à diversidade de manifestações culturais de rua, expressa pelo trabalho de vários "artistas de rua"3 que já fazem parte do cotidiano dessa cidade. Cada artista possui características comuns e especificidades em relação ao seu trabalho e atraem um grande público em suas apresentações, as quais são verdadeiros espetáculos ao ar livre, aglutinando pessoas de camadas sociais distintas. Quem transita por locais de grande afluência poderá encontrálos cercados de observadores curiosos. Muitos desses eventos culturais são manifestações populares que ocorrem no espaço da rua ao longo de muitos séculos, pois o oficio de "artista de rua" é muito antigo.

Alguns autores, como Peter Burke (1989) e Milkhail Bakhtin (1996), examinaram, em suas obras, a forma de trabalho dos artistas que se apresentavam nas ruas e feiras, transitando de cidade em cidade, divertindo o público com suas brincadeiras que faziam rir e, muitas vezes, criticando de forma debochada e brincalhona a sociedade em que viviam.

Em Peter Burke (1989, p.118-121), pode-se encontrar uma abordagem sobre os tipos de artistas populares que atuavam pelas ruas na Idade Média. Eles eram profissionais de diversão itinerantes, que apresentavam espetáculos de variedades e que recebiam denominações bastante diversas. Na Inglaterra, entre 1500 e 1800, por exemplo, eram chamados de "bufões", "palhaços", "comediantes", "malabaristas", "acrobatas", "charlatões", "saltimbancos", "tocadores", "curandeiros" e "apresentadores de espetáculos". Muitos desses artistas viajavam com seu teatro mambembe pelas cidades ou feiras parando nas aldeias que existiam pelo caminho.

\footnotetext{
1 Este estudo tem como origem minha dissertação de mestrado defendida em maio de 2001, no Programa de PósGraduação em Antropologia da Universidade Federal do Rio Grande do Sul, sob a orientação da Profa. Dra. Maria Eunice de Souza Maciel.

${ }^{2}$ Mestre em Antropologia Social e Pesquisadora Associada no Núcleo de Antropologia Visual - UFRGS.

3 A expressão "artistas de rua" é uma das denominações utilizadas pelos informantes, que abrange, de forma geral, aqueles que apresentam seus espetáculos pelas ruas da cidade de forma autônoma e, na maioria das vezes, itinerante.
} 
Atualmente pode-se ver nas ruas ou praças de Porto Alegre os espetáculos de muitos artistas integrados ao cotidiano urbano. Neste artigo, irei focalizar minha atenção nos "espetáculos de rua" de dois artistas que atuam no Largo Glênio Peres, centro de Porto Alegre, e de outro que atua no Brique da Redenção.

Esses "artistas de rua" possuem uma certa semelhança com os chamados "tocadores" ambulantes, abordados na obra de Peter Burke (1989, p.121), no que diz respeito a uma história de trabalho itinerante. Todos já realizaram espetáculos viajando de cidade em cidade, como também percorrendo as ruas do centro de Porto Alegre, sem ter lugar definido para realizar suas apresentações. Hoje, os que atuam no Largo não são itinerantes porque encontraram nesse espaço um lugar fixo para trabalhar.

Este trabalho se propõe a verificar como os "artistas de rua" articulam elementos da vivência cotidiana e constroem, assim, um espetáculo que atrai um grande público. Para auxiliar na compreensão de tais eventos, foi realizada a análise do vocabulário manifesto pelos artistas, sua interação com o público na situação de espetáculo e a influência do espaço nesses eventos.

A opção pela análise do vocabulário dos "artistas de rua" nas apresentações deve-se à diversidade de expressões verbais, as quais, na maioria das vezes, podem ser entendidas como "insultuosas", "grosseiras" ou "obscenas", mas que pertencem ao tipo de linguagem manifestada nos "espetáculos de rua". Para auxiliar na análise dessas formas de expressões verbais, utilizo a abordagem proposta por Milkhail Bakhtin (1996) que, ao analisar a obra de François Rabelais, constatou uma linguagem orientada pelo realismo grotesco e impregnada da tradição da cultura popular da Idade Média e do Renascimento com raízes na Antigüidade. Como o autor destaca, as injúrias, os julgamentos, as grosserias e as maldições faziam parte do linguajar familiar da praça pública. As expressões grotescas que se referiam ao baixo corporal, ou mais especificamente aos órgãos genitais, ao ventre e ao "traseiro", assim como à escatologia do corpo humano, faziam parte do tipo de vocabulário manifesto na praça pública e são retratadas na obra de Rabelais.

\footnotetext{
4 “Espetáculos de rua" é um dos termos utilizados pelos artistas para denominar suas apresentações no espaço da rua.
} 
É importante ressaltar os conceitos fundamentais utilizados neste trabalho para a análise dos "espetáculos de rua", como o de cultura popular, a partir de Michel de Certeau (1994); o de interação, de Goffman (1989, p.23), que diz respeito à interação estabelecida em uma relação face a face, em que há influência recíproca dos indivíduos sobre as ações uns dos outros; o de espaço, abordado por Roberto Da Matta (1997, p.15), e o de verossimilhança, de Magnani (1998, p.54). O conceito de espaço, quando empregado em relação ao Brique e ao Largo, diz respeito ao espaço da rua. Conforme Da Matta (1997, p.15), o espaço da "rua" e o da "casa" podem ser entendidos como categorias sociológicas, opostas e ao mesmo tempo complementares, pois não designam "[...] simplesmente espaços geográficos ou coisas físicas comensuráveis, mas acima de tudo entidades morais, esferas de ação social, províncias éticas dotadas de positividade, domínios culturais institucionalizados [...]". Nesse sentido, o uso da categoria "rua" refere-se às pessoas que freqüentam esse espaço, com seus gostos, valores e estilos de vida. Desse modo, os artistas buscam se orientar pelas características do espaço para que seus espetáculos criem o efeito de verossimilhança para o público. Conforme Magnani (1998, p.54), "para que um circuito discursivo qualquer se complete, é preciso que haja algum tipo de adequação entre suas significações e o sistema de representação dos receptores." O que caracteriza, portanto, o verossímil é sua semelhança.

Em se tratando de uma pesquisa antropológica que faz uso de dados qualitativos, este trabalho adotou o método etnográfico como aquele capaz de conduzir tanto às práticas quanto às representações simbólicas manifestadas nos "espetáculos de rua". Durante pesquisas de campo realizadas junto aos "artistas de rua", alguns espetáculos foram registrados em vídeo, auxílio valioso na investigação, na medida em que proporcionou o registro da dinâmica dos espetáculos, viabilizando a reprodução das falas dos artistas durante as apresentações. Foram realizadas também entrevistas não-diretivas, gravadas com os três artistas em bares do centro de Porto Alegre, e conversas informais no ambiente de trabalho.

\section{Largo Glênio Peres e Brique da Redenção - localização e breve descrição}

\subsection{Largo Glênio Peres}

A localização do Largo é privilegiada, pois está situado entre a Praça XV de Novembro e o Mercado Público central e entre a Av. Borges de Medeiros e a Praça Parobé, um dos principais pontos de ônibus no centro da cidade, ou seja, locais de grande circulação de pessoas, ônibus e 
automóveis. Atualmente, não existe estatística sobre o número de transeuntes que passam pelo Largo, mas segundo dados da Secretaria Municipal de Produção, Indústria e Comércio (SMIC), passam em frente do Chalé (na Praça XV de Novembro) diariamente cerca de 300 mil pessoas. ${ }^{5}$

A população do Largo é constituída tanto por itinerantes, pessoas que cruzam pelo local, quanto por aqueles que fazem parte do cotidiano desse lugar, como os meninos e as meninas que transitam por ali, chamados pelos artistas de "meninos de rua" ou de "lolozeiros", 6 como também algumas mulheres que diariamente trabalham circulando entre os transeuntes em busca de clientes, chamadas de "mulheres de viração" ou prostitutas. Há também homens que esporadicamente freqüentam os "espetáculos de rua" em busca de um parceiro sexual masculino; são denominados de homossexuais ou "bichas". Juntam-se a esses os "moradores de rua", assim chamados pelos artistas, porque muitas vezes amanhecem dormindo nos bancos ou nas imediações do Largo. O Largo também é local de cultos religiosos de pastores pentecostais fazendo suas pregações em alta voz em busca das adesões de novos fiéis.

Diariamente há um grande número de artistas itinerantes que, quando estão em Porto Alegre, realizam seus "espetáculos de rua" nesse espaço. Eles vêm dos mais variados lugares do país, como São Paulo, Rio de Janeiro, Bahia e Pernambuco, entre outros estados, e também de outras cidades do Rio Grande do Sul. Entretanto, para trabalhar no Largo, precisam da permissão de dois artistas, Pedro e Chaves, considerados os “donos do ponto”, cujos espetáculos são analisados neste artigo.

\subsection{O Brique da Redenção}

O Brique da Redenção reúne todos os domingos os mais diversos tpos de atrativos culturais e comerciais ao ar livre. Localiza-se na rua José Bonifácio, entre duas importantes avenidas: Osvaldo Aranha e João Pessoa, no bairro Bom Fim, e ao lado do Parque Farroupilha, ou como é popularmente chamado, Parque da Redenção.

O horário de funcionamento é das nove às dezoito horas e, durante esse período, diversas tendas de expositores ocupam o canteiro central que divide a rua José Bonifácio em duas pistas. Também nesse horário o trânsito de veículos é interrompido, ficando a rua exclusivamente disponível para a circulação das pessoas. Inaugurado em 1978, hoje abarca 300 expositores distribuídos entre quatro segmentos: Feira de Antigüidades, Feira de Artesanato, Feira de Artes

Plásticas e Feira de Gastronomia. Atualmente o Brique abarca em torno de 180 artesãos. É um espaço de sociabilidade em que se reúnem amigos, colegas, vizinhos e familiares para conversar 
sobre suas vidas, trocar idéias sobre os mais diversos assuntos e descansar da rotina do trabalho dos dias da semana.

Assim como o Largo Glênio Peres, o Brique é um espaço de manifestações políticas e sociais em que se pode encontrar, por exemplo, em períodos eleitorais, candidatos a cargos eletivos, grupos de filiados e simpatizantes fazendo campanha. Segundo dados da SMIC de 1990, circulam pelo Brique aproximadamente 40 mil pessoas a cada domingo ${ }^{7}$.

O Brique da Redenção abarca diversos tipos de manifestações espontâneas, que vieram a fazer parte do cotidiano desse espaço. Na maioria das vezes, são realizadas por artistas itinerantes que atuam em diferentes pontos da cidade durante a semana, mas que, aos domingos, se deslocam para esse espaço. Essa concentração dá ao local uma característica especial, que é a existência de várias apresentações que ocorrem simultaneamente durante seu funcionamento. Ao longo da Rua José Bonifácio, podem ser vistos grupos de capoeiristas, que atraem o público pela música e pela animação; músicos oriundos de toda a América Latina, que se apresentam cantando e tocando instrumentos típicos; "estátuas vivas", denominação dada para os artistas que imitam estátuas de personagens reconhecidas pela imobilidade dos artistas, que apenas realizam movimentos quando alguém deposita a seus pés um pagamento em dinheiro, e palhaços que desfilam pelo Brique, realizando brincadeiras e chamando a atenção das crianças com balões coloridos e outros tipos de brinquedos. Entre as várias manifestações no Brique, estão também os "espetáculos de rua" de Feliciano, que atraem a atenção pelo seu caráter circense.

É importante salientar que existe uma considerável diferença entre os espaços Brique da Redenção e Largo Glênio Peres. No Largo, os "espetáculos de rua" ocorrem durante a semana, em um tempo reservado ao trabalho; no Brique, acontecem aos domingos, tempo dedicado ao lazer. ${ }^{8}$ Outra diferença é que, no Largo, grande parte do público que permanece nos espetáculos é oriundo de grupos populares e, no Brique, de camadas médias da sociedade.

\footnotetext{
${ }^{5}$ Dados do Jor nal Zero Hora (29.10.98, p.67).

6 "Lolozeiro" é aquele que faz uso de "loló", substância psicoativa feita a partir da cola de sapateiro.
} 
Pedro, o espaço do Largo é concebido "apenas para grandes e pequenos eventos culturais". Ele afirma que, atualmente, é o único a ter permissão legal da SMC para trabalhar, realizando apresentações com bonecos. Por esse motivo, sente-se "dono do ponto". Quando necessário, mostra sua carteira de sócio da Seção Brasileira de Teatro de Rua, que legitima seu ofício de "bonequeiro".

Em 2000, quando foi escrita minha dissertação, Pedro tinha 48 anos de idade e há 21 trabalhava como ventríloquo. Iniciou o ofício de "artista de rua" na Praça da Alfândega, centro de Porto Alegre, aprendendo a manipular os bonecos dos artistas que ali se apresentavam. Nessa ocasião, conheceu Chaves, que trabalhava na Praça, e passou a lhe ensinar a arte da ventriloquia.

Em 1992, Pedro migrou para o Largo, porque desejava ter o seu próprio "ponto" de trabalho, convidando o amigo e mestre Chaves para compartilhar o local.

Atualmente Pedro é conhecido, no centro da cidade, como o "homem do boneco", porque, em seus espetáculos, manipula um boneco de madeira construído por ele, cujo nome é Peteleco. O boneco é negro, possui um pescoço longo, que se movimenta para todos os lados, observando as pessoas que o cercam para, em seguida, brincar com elas. Peteleco assume o papel de brincalhão durante os espetáculos dizendo versos e piadas debochadas e atrevidas para o público.

A venda de remédios também faz parte do seu trabalho. Era por meio da comercialização de pequenas latinhas, que continham uma espécie de pasta ou pomada chamadas de "banha do peixeboi do Amazonas" ou "banha do peixe elétrico do Amazonas", que o artista ganhava na época, cerca de 40 reais por dia.

Apesar da comercialização de produtos, Pedro não se denomina "propagandista", como seu colega Chaves. O artista chama seu espetáculo de "teatro popular".

O "propagandista" Chaves, na ocasião da minha pesquisa, tinha 62 anos de idade; sua primeira experiência como artista ocorreu aos 13 anos como ajudante nos espetáculos de um mágico que conheceu na rua. Natural de Lavras do Sul, aos 14 anos mudou-se para Porto Alegre em busca

\footnotetext{
${ }^{7}$ Essa estimativa de 1990 é a mais recente realizada sobre o Brique da Redenção.

${ }^{8} \mathrm{O}$ lazer a que me refiro aqui é aquele desfrutado nos fins de semana no espaço da rua, mais especificamente no Brique da Redenção. Conforme Joffe Dumazedier (1973, p.34): “O lazer é um conjunto de ocupações às quais o indivíduo pode entregar-se de livre vontade, seja para repousar, seja para diverti-se, recrear-se ou, ainda, para desenvolver sua informação ou formação desinteressada, sua participação social voluntária ou sua livre capacidade criadora após livrar-se ou desembaraçar-se das obrigações profissionais, familiares e sociais."
} 
de emprego. Em meados de 1954, a convite de um amigo, Chaves passou a vender alguns produtos na praça Parobé e, em seguida, a participar dos espetáculos de artistas "propagandistas" que se apresentavam no local. Conforme Chaves, é "propagandista" quem comercializa produtos medicinais, explicando sua utilidade e o modo de usá-los durante os espetáculos ou mesmo fora deles $^{9}$.

Os "espetáculos de rua" de Chaves são realizados por meio de brincadeiras com o público envolvendo mágicas e divulgação e comercialização de remédios como o "óleo da espinheira da jibóia branca do Pará" e o "guaraná tônico". Ao final do dia, ele obtém cerca de 30 a 40 reais, incluindo o que recebeu durante os espetáculos e fora deles.

\subsection{Feliciano}

Feliciano é conhecido popularmente na cidade como o "homem do gato" devido ao personagem que representa em seus "espetáculos de rua". Nascido em Recife (PE), já morou em Florianópolis e no Rio de Janeiro, onde deu origem ao personagem "homem do gato". Na época de meu trabalho de campo ele tinha 45 anos e há 27 apresentava seu espetáculo, sendo que 17 desses em Porto Alegre.

Feliciano chama seu espetáculo de "Show do gato" e considera seu trabalho um "teatro humorista", "teatro de rua". Conforme Feliciano:

O homem do gato surgiu justamente num dia em que eu vi um cara brincando com um gato numa caixa, no Rio, na festa de Nossa Senhora da Penha. E aí eu disse pra ele que deixasse comigo que eu ia fazer melhor do que ele. Aí eu peguei a caixa e botei dentro de um saco e ali começou o primeiro "show do gato". Dali em diante, eu larguei tudo e passei a ser somente o "homem do gato"[...]. Eu criei a idéia de matar o gato dentro do saco, criei uma cena de violência para chamar a atenção das pessoas e ali fazer um teatro. Esse homem tinha uma caixa de papelão e apenas a cutucava fazendo como estivesse um gato ali dentro, mas não juntava tanto público; as pessoas ficavam curiosas e ele dizia que tinha um apitinho e vendia, mas ele vendia pouco proporcionalmente ao que eu vendo, por exemplo. E eu transformei essa idéia num espetáculo.

9 É durante a situação de espetáculo e fora dessa que os artistas Chaves e Pedro vendem seus produtos medicinais a pedido das pessoas. 
A apresentação do artista consiste em brincar de matar um gato dentro de um saco de estopa aplicando vários golpes com um pedaço de taquara. $\mathrm{Na}$ verdade, o suposto animal é uma boina de veludo preto, que é presa por uma corda e puxada pelo artista. Durante o show, executa brincadeiras, contando piadas e causos e estabelecendo situações cômicas que envolvem o público.

Durante os dias de semana, Feliciano realiza seu espetáculo nas ruas do centro de Porto Alegre e, aos domingos, no Brique da Redenção. Em um domingo de apresentação, chega a arrecadar aproximadamente 200 reais. Esse dinheiro é adquirido por meio de contribuições oferecidas durante os espetáculos e da venda de alguns produtos, que atraem principalmente a atenção das crianças, como gomas de mascar de anilina e pimenta, barbantes, que, ao serem queimados, exalam odores, chamados pelo artista de "peido alemão", "peido de negrão" e "peido de velha"; objetos com a forma de excrementos, confeccionados a partir de folhas de jornais e argila nos tamanhos grande, médio e pequeno, denominados de "cagadas", e apitos feitos de bambu, que Feliciano chama de "apito do gato". Esses produtos são fabricados sob o comando do próprio artista.

\section{O oficio de "artista de rua"}

Pedro, Chaves e Feliciano possuem trajetórias de vida distintas. Feliciano concluiu o ensino médio, fez cursos de teatro no Rio de Janeiro e é reconhecido legalmente como ator, locutor e apresentador, sendo filiado aos sindicatos dessas categorias em Porto Alegre. Os artistas Chaves e Pedro não completaram os estudos no ensino fundamental, e a formação como artistas se deu na observação de trabalhos de outros profissionais e na própria prática cotidiana. É importante salientar que, para os artistas, o "verdadeiro" aprendizado sobre o ofício de "artista de rua" ocorreu nas ruas com a prática do dia-a-dia.

Segundo Pedro, Chaves e Feliciano, o que os direcionou a tal atividade foram as "vantagens" de escolha de horários e a possibilidade de administrar a própria atividade profissional. Os "artistas de rua" possuem liberdade de escolher onde, como e quando trabalhar. Decidem as ruas em que se apresentam, de preferência as de maior circulação de pessoas, e os horários que julgam apropriados para realizar seus espetáculos. Por outro lado, a liberdade de escolha dos lugares para realização dos espetáculos está limitada àqueles que não estão ocupados por outros colegas de profisssão.

A "vida dura" dos artistas é muito comentada por eles. Seguidamente reclamavam para mim dos maus tratos que recebiam de algumas pessoas que não compreendiam o trabalho, chamando-os 
de "vagabundos". As queixas sobre o tempo frio, chuvoso ou muito quente eram sempre manifestas como justificativas para o fato de não conseguirem ganhar dinheiro, pois os espetáculos dependem muito desses fatores climáticos.

Os artistas possuem formas distintas de "espetáculos de rua", que são oriundas de uma escolha orientada por de suas experiências de vida observando e atuando junto a outros artistas, que, muitas vezes, os introduziram no ofício de "artista de rua". A forma como realizam seus espetáculos está também diretamente ligada à trajetória que esses artistas percorreram. Chaves foi influenciado pelos colegas de trabalho que exerciam as atividades de mágico e "propagandistas". Os reflexos de tais influências podem ser percebidos em seus espetáculos, pois envolvem mágicas e comercialização de remédios.

Pedro aprendeu com Chaves a arte da ventriloquia e também da venda de produtos, mas seu espetáculo, como ele próprio diz, “[...] é mais 'teatro popular’ do que venda propriamente dita [...]"porque dedica a maior parte do tempo para contar piadas, brincar com o boneco Peteleco e fazer rir do que para realizar espetáculos voltados para divulgação e venda de produtos, como o "propagandista" Chaves.

Feliciano aprendeu o ofício observando um "artista de rua" no Rio de janeiro e, a partir de suas observações, criou sua própria forma de espetáculo envolvendo piadas, a "briga com o gato" e a venda de produtos. Entretanto, todos os artistas demonstram características em comum: uma delas é a capacidade de incorporar acontecimentos da vida cotidiana em seus espetáculos, por exemplo, as notícias de jornais, revistas e televisão, assim como de utilizar falas e gestos dos espetáculos de seus colegas. Então, com esses elementos, constroem seus espetáculos como um bricoleur, que, a partir de formas já existentes, monta sua obra de arte. Outra característica peculiar do oficio é ser ou ter sido itinerante. Atualmente, Pedro e Chaves possuem um "ponto" fixo no Largo, mas anteriormente atuavam em diversos lugares da cidade. Já Feliciano, durante a semana, circula com seu espetáculo pelas ruas do centro de Porto Alegre; no período de verão, trabalha nas praias do litoral gaúcho ou fora do estado. É importante ressaltar, ainda, que existe outra importante característica dos espetáculos em questão, que é o caráter circense acentuado, pois eles compartilham de formas tipicamente reconhecidas em representações de circo, como as mágicas e a forma bufônica do palhaço. 


\section{Aspectos comuns nos "espetáculos de rua": observando o público para a realização de brincadeiras}

O bom desempenho nos espetáculos depende tanto da escolha do espaço utilizado para a apresentação quanto da constante observação das pessoas que transitam por ele e daquelas que param para assistir às apresentações. Durante os espetáculos, os artistas ficam atentos ao comportamento do público tendo em vista alguns sinais, como vestuário, idade, sexo, altura, aparência, atitude, expressões faciais, gestos corporais e forma de linguagem, que podem servir como fonte de informação sobre quem é esse público.

Manter o público interessado nos espetáculos é uma tarefa que depende, em grande parte, da forma como o "artista de rua" articula sua fala. Saber falar com o público é fundamental para mantêlo na "roda". ${ }^{10} \mathrm{O}$ vocabulário utilizado é direcionado para os tipos de pessoas que assistem às apresentações com a intenção de atrair sua atenção. Conforme Pedro:

No nosso trabalho, certo tipo de palavrão não é permitido, mas há necessidade de dizer para que tenha graça [...] onde tem muitas mulheres na "roda", já não é permitido dizer porque duas gostam, mas tem dez que já se sentem ofendidas moralmente [...] quando tem mais homens, aí pode dizer mais palavrões [...] As brincadeiras com as mulheres geralmente são insinuantes... tem que ver o tipo de mulher que está na "roda", as acima dos quarenta anos de idade eu já não gosto de fazer porque já são senhoras moralistas. Geralmente pessoas nessa idade já não gostam tanto [...] As "mulheres de viração" eu faço brincadeiras mais pesadas, elas não se ofendem, sempre tem umas que querem se impor, mas mesmo elas não se ofendem porque dentro daquela brincadeira que eu faço de repente elas estão arranjando um programa.

Quando o artista desconhece seu público, deixa-se conduzir pela conduta e aparência das pessoas nos espetáculos para, assim, direcionar as brincadeiras. Quando algumas pessoas the são familiares, pois já conhecem aspectos de suas vidas, sentem-se mais livres para realizar brincadeiras mais audaciosas, como é o caso de Pedro em relação às prostitutas que atuam no local. Dessa forma, eles escolhem, nas "rodas", algumas pessoas que se enquadram no repertório de brincadeiras que costumam realizar. É importante ressaltar que os espetáculos são construídos com um repertório de brincadeiras executadas de acordo com a aceitação do público. Nesse sentido, o improviso é

\footnotetext{
${ }^{10}$ Expressão êmica que corresponde ao público que circunda os artistas na situação de espetáculo.
} 
fundamental para que o espetáculo seja bem-sucedido, porque nem sempre o artista possui a brincadeira apropriada para a situação que se apresenta num dado momento. O improviso não se dá somente ao escolher uma brincadeira ou outra, mas principalmente durante a própria execução da brincadeira, uma vez que depende da interação estabelecida com o público. Uma brincadeira nunca é executada da mesma forma, porque cada evento possui uma forma de interação própria do momento em que ocorre. Considerando que o público está em constante movimento, justifica-se o caráter singular de cada apresentação. A personagem improvisa e, se o público demonstrar aceitação, que geralmente é expressa pelo riso, que serve também como sinalizador de verossimilhança (MAGNANI, 1998), a brincadeira passa a ser incorporada entre as já existentes.

\section{A interação entre artista e público}

Para compreender como ocorre a interação entre artista e público nesses tipos de manifestações culturais, deve-se pensá-la como fruto de uma relação estabelecida em uma situação de espetáculo.

Os "espetáculos de rua" criam um ambiente de brincadeiras que sugere o riso das pessoas que formam as "rodas" e, para que se mantenha nessa situação de brincadeira, é importante que o público aceite as regras impostas pela situação que se apresenta. As pessoas que assistem às apresentações são interpeladas de diversas formas pelos "artistas de rua" e, às vezes, demonstram não gostar do tipo de brincadeira em que são envolvidas, vindo a sair das "rodas" ou verbalizando em alta voz seu descontentamento. Para que o espetáculo permaneça na situação de brincadeira, é preciso que o público perceba que tal manifestação faz parte de um jogo em que as pessoas são convidadas a participar e aceitar as formas de interpelação como parte desse momento ritual de atitudes e gestos.

Conforme Huizinga (1971, p.11), o jogo possui características, como o fato de ser livre, não ser vida real, ou seja, “[...] trata-se de uma evasão da vida 'real' para a esfera temporária de atividade com orientação própria”. É um faz-de-conta praticado dentro de limites temporais e espaciais com regras que determinam o que vale dentro do mundo temporário por ele circunscrito.

\section{Os “espetáculos de rua” no Largo e no Brique}

\subsection{O “teatro popular" de Pedro}

Normalmente Pedro inicia seus espetáculos nos horários de maior movimento: em torno do meio-dia até aproximadamente as 13 horas e 30 minutos, que corresponde ao intervalo de trabalho 
geralmente concedido para o almoço, e nos finais de tarde, por volta das 17 horas e 30 minutos, horário em que os trabalhadores estão voltando para casa.

$\mathrm{O}$ artista começa a atrair a atenção dos transeuntes quando coloca um microfone em seu pescoço, que está acoplado a um alto-falante, e passa a regular o volume dos ruídos e das palavras que pronuncia. Costuma iniciar o espetáculo anunciando como atração alguns animais peçonhentos, como aranhas ou cobras. Para isso, observa atentamente o comportamento do público com a intenção de moldar sua apresentação de acordo com sua percepção sobre o que fará a platéia se sentir atraída a permanecer na "roda". Algumas pessoas que julga ter "estudo mais elevado" não gostam da brincadeira da cobra, querem ouvir o "argumento", portanto é desenvolvida uma brincadeira que as faça rir. Ele próprio diz que algumas pessoas freqüentam seus espetáculos para rir, “descarregar o stress" ocasionado no trabalho. Portanto, percebendo os motivos que levam as pessoas a freqüentar as "rodas", o artista molda suas brincadeiras de acordo com o que acredita ser esperado, nesse caso piadas e ventriloquia. A preocupação com a forma de abordar o público tem sua justificativa, pois o Largo Glênio Peres é um espaço onde circulam os mais variados “tipos de pessoas” como diz Pedro.

No "teatro popular" do ventríloquo, é o boneco Peteleco quem chama a atenção do público. A cada brincadeira, o público reage rindo e quase sempre fazendo comentários sobre a audácia do boneco, que, na maioria das vezes, é advertido pelo artista com severos tapas no rosto que produzem um forte estampido.

Em busca do riso e da descontração, Pedro desenvolve um duplo papel: o de Peteleco, um jovem malandro, brincalhão e abusado, e o de um adulto educador que repreende o boneco. A graça está que o boneco não se deixa abater com a repreensão e continua a fazer seus comentários jocosos. $\mathrm{O}$ boneco é um recurso artístico de expressão verbal e corporal utilizado por Pedro que remete as pessoas ao mundo da fantasia, onde os temas "reais" são mencionados com significações cômicas.

O espetáculo de ventriloquia é constituído principalmente de brincadeiras que ressaltam, de maneira cômica, características do público. Peteleco envolve o público brincando, chamando a atenção para a careca de um homem, para o sapato sujo ou para a barba grande de outro. O artista scolhe algumas pessoas na "roda" que se enquadram em seu repertório de brincadeiras para, por meio do boneco, interpelá-las. $\mathrm{Na}$ maioria das vezes, as pessoas envolvidas são aquelas que assistem seguidamente aos espetáculos ou que fazem parte do cotidiano do Largo. Muitas são consideradas pelos artistas como fazendo parte do "pedaço" ". É o caso das prostitutas que, quando presentes nas "rodas", são interpeladas pelo artista. As brincadeiras direcionadas a elas são, conforme Pedro, as 
"mais pesadas". O que ocorre nesse tipo de interação é uma certa troca de favores: a maioria das mulheres que trabalha no Largo como prostituta aceita ser interpelada com brincadeiras "mais pesadas" nos espetáculos de Pedro, contribuindo, assim, para o sucesso do evento. Em troca, sabem que as atenções de alguns homens do público serão voltadas para elas e, com isso, podem conseguir alguns clientes. Esta é uma das lógicas particulares desse "pedaço", no centro da cidade, onde as pessoas convivem diariamente estabelecendo as mais diversas trocas de favores. No entanto, a presença delas na "roda" também está relacionada com a procura de diversão, como o fazem os "meninos de rua", que são parte do dia-a-dia desses eventos. Percebo que muitas vezes se divertem assistindo aos espetáculos. Apesar de já conhecerem muitas das brincadeiras realizadas, sempre há algo de novo. Possivelmente os "espetáculos de rua" sejam a forma de lazer mais próxima de suas possibilidades. Trabalhadores da região também comparecem nas apresentações para rir, se divertir, conversar com os artistas, por exemplo, engraxates, açougueiros, funcionários de bancos e secretários que trabalham no centro.

Tendo em vista essas constatações, considero que tais espetáculos fazem parte de um "campo de possibilidades"12 oferecido como lazer no centro da cidade, tanto para as pessoas que fazem parte do cotidiano desse espaço, quanto para as que trabalham nas imediações do Largo. Além disso, há ainda aqueles que, de passagem, param um instante, observam o espetáculo, às vezes fazem algum comentário, riem e retomam seu caminho. Daí a importância de considerar os "espetáculos de rua" no Largo como momentos de suspensão do tempo do trabalho, o tempo oficial, aquele que orienta a rotina na cidade, chegando a constituir instantes de lazer experimentados pelos trabalhadores nos intervalos ou no final do expediente. A idéia dos "espetáculos de rua" como propiciadores de momentos de suspensão do tempo do trabalho foi abordada por Luciana Carvalho, em sua dissertação "Espetáculos de rua" no Largo da Carioca. ${ }^{13}$ Ao analisar a forma de vocabulário e de interação estabelecida na situação de espetáculo no Largo da Carioca, a autora considerou tais eventos como momentos de suspensão do tempo do trabalho, ressaltando que o público das "rodas", após assistir aos espetáculos e vivenciar momentos de riso, retorna ao tempo ordinário revitalizado para continuar o dia-a-dia de trabalho.

\footnotetext{
${ }^{11}$ Ver MAGNANI, José Guilherme C. Festa no Pedaço: Cultura Popular e lazer na Cidade. São Paulo: Brasiliense, 1998.

12 Ver VELHO, Gilberto. "Unidade e Fragmentação em Sociedades Complexas" In: Projeto e Metamorfose. Antropologia das Sociedades Complexas. Rio de Janeiro: Jorge Zahar,1994, p. 27.
} 
Assim como realiza brincadeiras "mais pesadas" com algumas mulheres, é também freqüente Pedro usar expressões como mulher "direita", "honesta", dirigidas a outras mulheres que formam a "roda", principalmente se elas estão desacompanhadas. Pedro responde às interpelações insultuosas de Peteleco em relação às mulheres, ressaltando esses valores e afirmando que se trata de "mulheres de família", "direitas" e "honestas, deixando subtendido que não podem ser tratadas de forma desrespeitosa por estarem sozinhas no Largo. O que está por trás desses tipos de brincadeiras é que o espaço da rua, o Largo, no caso, não é lugar de mulher, principalmente desacompanhada da figura masculina. ${ }^{14}$ Portanto, a idéia sobre o espaço da rua reservado ao homem influencia nas formas das brincadeiras realizadas com as mulheres que freqüentam as "rodas".

É característica predominante nos espetáculos a presença de um vocabulário ambivalente que, inicialmente, comete insultos e em seguida elogia. Observe-se, a seguir, um trecho do espetáculo em que o boneco se dirige para alguém do público dizendo "Oi, colega" e Pedro o adverte: ${ }^{15}$

$\begin{array}{ll}\text { PEDRO - O senhor não tem colega. } & \text { PETELECO - Não, senhor. } \\ \text { PETELECO - Tenho. } & \text { PEDRO - Ele é colega seu } \\ \text { PEDRO - Não tem. } & \text { daonde? } \\ \text { PETELECO - Tenho. } & \text { PETELECO - Da cadeia né, } \\ \text { PEDRO - Cadê o seu colega? } & \text { negrinho? Te largaram ou tu fugiu? } \\ \text { PETELECO - Aí, hein, negrão! } & \text { (Plaft - Pedro dá um tapa no rosto } \\ \text { (O interpelado e as pessoas do } & \text { do boneco, fazendo o interpelado } \\ \text { público manifestam-se rindo.) } & \text { e outras pessoas do público rirem.) } \\ \text { PEDRO - Você por acaso trabalha } & \text { PEDRO - Fica quieto, rapaz! É um } \\ \text { com ele? } & \text { pai de família, trabalhador, tra- } \\ \text { PETELECO - Não. } & \text { balha o dia inteiro. } \\ \text { PEDRO - Mora com ele? } & \text { PETELECO - De noite rouba, né } \\ \text { PETELECO - Deus me livre! } & \text { negrão? } \\ \text { PEDRO - Joga bola com ele? } & \text { PEDRO - Fica quieto, rapaz! } \\ \text { PETELECO - Não. } & \text { Como você vai mexer com as } \\ \text { PEDRO - Já sei, você estuda com ele? } & \text { pessoas desse jeito, Peteleco? } \\ & \text { Está vendo que ele está sempre } \\ & \text { aqui assistindo o senhor? [...] }\end{array}$

\footnotetext{
${ }^{13}$ Ver CARVALHO, Luciana G. Os "espetáculos de rua” no largo da Carioca. 1997. Dissertação (Mestrado em Antropologia) Programa de Pós-Graduação em Antropologia, UFRJ, Rio de Janeiro, 1997.

${ }^{14}$ Confrome Da Matta (1997, p.30): "O espaço se confunde com a própria ordem social, de modo que, sem entender a sociedade com suas redes sociais e valores, não se pode interpretar como o espaço é concebido.”
} 
Constata-se o vocabulário ambivalente quando Pedro reprime as interpelações insultuosas de Peteleco dando-lhe um tapa no rosto e, em seguida, explicando como deve se comportar, com educação, por exemplo em relação ao trecho acima, respeitando o homem que é negro, mas é pai de família e trabalhador. Essa forma de elogiar integrantes do público ressaltando o valor trabalho é frequiente e pode-se dizer que é uma das influências que o meio exerce em tal evento. Os espetáculos ocorrem durante a semana, num tempo reservado ao trabalho; a forma de tratamento do artista para com o público está diretamente relacionada com essa circunstância. Para conquistar a simpatia do público, é importante salientar valores que lembrem aos presentes que aquelas pessoas insultadas por Peteleco são trabalhadoras. Não interessa, aqui, saber se os indivíduos presentes nas "rodas" são realmente trabalhadores ou não, se a fala de Pedro condiz com a realidade dos interpelados e, sim, que a capacidade do artista de prender a atenção do público e fazê-lo rir de suas brincadeiras está na verossimilhança entre as significações do que é dito pelo artista e as idéias que a platéia tem acerca dessas significações.

\subsection{Os "espetáculos de rua" do "propagandista" Chaves}

Chaves costuma realizar suas apresentações antes ou logo em seguida às de Pedro. Quando antecede o colega, executa brincadeiras que envolvem truques com cartas de baralhos ou moedas. Algumas vezes, com auxílio de uma pequena sineta, anuncia o aparecimento de uma cobra. Por outro lado, quando aproveita o "pano de roda"16, parte diretamente para a divulgação de seus produtos, a "espinheira da jibóia branca" e o "guaraná tônico".

A maneira de trabalhar do "propagandista" Chaves é por meio de brincadeiras que não são direcionadas para uma pessoa específica da platéia, como as realizadas por Pedro. Quando as faz, é de forma cautelosa. Ao convidar alguém da "roda" para experimentar os seus remédios, sempre se dirige de forma "respeitosa" usando tratamentos como: "senhor", "senhora", “compadre", "amigo",

\footnotetext{
15 Trecho selecionado de uma filmagem realizada em 1994 pelo antropólogo Rogério Rosa com colaboração de Neiva Rosa Garcia. O vídeo encontra-se à disposição na videoteca do Núcleo de Antropologia Visual - Campus do Vale - UFRGS.

${ }^{16}$ Em muitas ocasiões, os "artistas de rua", após o término dos espetáculos, convidam outros colegas de trabalho para se apresentar ao público que permanece à sua volta. Esse momento, em que o artista está finalizando o espetáculo e ainda há pessoas assistindo à apresentação, é denominado de "pano de roda". Quando isso acontece, os que aproveitam o momento consideram mais fácil realizar seu trabalho porque já existe um público formado à espera do espetáculo.
} 
"distinto pai de família", "pessoas educada". Utiliza expressões como "por favor", "por gentileza". Essa forma de abordar o público é constante nos espetáculos de Chaves e pode ser evidenciada no trecho abaixo, onde o artista percorre a "roda" oferecendo seu produto, a "espinheira da jibóia branca do Pará," para as pessoas mais próximas, dizendo: ${ }^{17}$

[...] eu vou botar uma gotinha deste óleo (na palma) da mão de cada pessoa educada que me estender a mão. (Chaves se aproxima de um homem do público para oferecer o produto e este lhe estende a mão.) Por gentileza, me faz um favor aqui, o senhor feche a mão ao sentir a gota cair na mão. $O$ senhor feche a mão. (Chaves pede para que outro homem experimente também e esse aceita estendendo a mão.) O senhor me faz favor aqui, distinto pai de família. (Oferece a uma mulher, que não recusa). Aqui a senhora, por gentileza e bondade, me faça esse favor para mim [...]

A forma de tratamento "respeitosa" usada na interação das pessoas está diretamente ligada ao espaço em que o espetáculo ocorre. Conforme mencionado anteriormente, as apresentações do artista são realizadas durante a semana num tempo reservado ao trabalho. A maioria dos que freqüentam as "rodas" são trabalhadores que aproveitam o intervalo de trabalho para dar "uma olhadinha" nos espetáculos e para comprar os produtos. Normalmente o público que permanece na "roda" do "propagandista" é composto por pessoas que o artista chama de "pessoas simples", "pessoas humildes" ou pessoas "pobres". Portanto, tendo consciência do perfil do público que permanece nas "rodas", Chaves, em geral, age de maneira "respeitosa", utilizando formas de tratamento como as mencionadas na citação em que divulga o produto, para que as pessoas se sintam importantes, respeitadas, valorizadas e suas interpelações sejam verossímeis. Talvez essas pessoas não sejam, em outros momentos do cotidiano, tratadas de tal forma, e esse tipo de tratamento seja aquele que julgam apropriado às pessoas de melhor condição social. Por esse motivo, interagem com o artista estendendo a mão e confirmando com a cabeça quando solicitadas, chegando mesmo a adquirir os remédios. $^{18}$

Percebe-se que, nos espetáculos, a maioria das pessoas abordadas sente-se respeitada e valorizada com a forma de tratamento que o artista oferece, o que pode ser atestado pela compra dos produtos. Tal maneira "respeitosa" de interpelar as pessoas contribui para que elas retornem outras vezes ao Largo para assistir aos espetáculos e adquirir as "mercadorias".

17 Trecho extraído de uma filmagem realizada em 1994 pelo antropólogo Rogério Rosa com colaboração de Neiva Rosa Garcia. O vídeo encontra-se à disposição na videoteca do Núcleo de Antropologia Visual - Campus do Vale - UFRGS.

18 Nos espetáculos de Chaves, então, o público interage da maneira diferente do público que assiste aos espetáculos de Pedro, que também se expressa com gestos, mas principalmente do riso, porque essas apresentações possuem um caráter cômico. 
Chaves considera que, para ser um "bom propagandista", deve explicar com cautela ao público a utilidade e o modo de usar o produto. Durante o "espetáculo de rua" como também fora dele, Chaves se dirige às pessoas de forma "respeitosa" e atenciosa, explicando com paciência como deve usar seus remédios. Diferentemente da forma de interpelar o público utilizada pelo artista Pedro, o vocabulário manifesto nos espetáculos de Chaves configura-se no avesso das "indelicadezas". 19

As brincadeiras envolvem um certo controle do vocabulário, pois o uso de palavrões nos espetáculos de Chaves não é recorrente. Conforme o artista:

“[...] eu nunca juntei uma 'roda' para falar bobagem, palavra pornográfica. Eu sou um cara que me cuido muito, muito mesmo! Eu conto piada, mas eu deixo o veneno para a cabeça da pessoa. Malícia eu não completo, eu levo bem pertinho e deixo para a cabeça da pessoa completar [...]"

Essa maneira de agir é também uma forma de atribuir credibilidade aos produtos que são comercializados, porque uma posição mais séria do artista em relação ao vocabulário utilizado para se dirigir ao público demonstra respeito por ele e pelo produto oferecido.

Uma característica importante do modo de trabalhar do artista, assim como dos demais analisados neste artigo, é o fato de ele observar o comportamento do público que frequienta as "rodas" para depois realizar a apresentação. Como o próprio Chaves expressa, "[...] tem que saber analisar o comportamento para trabalhar [...] eu não tenho estudo, mas tenho psicologia [...]", ou seja, tem que se ter habilidades e talento para realizar tal oficio. Não é qualquer pessoa que possui essa destreza, portanto, a atividade que exerce é um trabalho especializado.

\subsection{Os "espetáculos de rua" de Feliciano: o "show do gato"}

Feliciano, o chamado "homem do gato", não tem horário definido para atuar no Brique da Redenção, mas nas ocasiões em que acompanhei seus espetáculos, chegou no local por volta das 14 horas.

19 Sobre a forma de interpelar o público realizada por artistas que comercializam remédios, Bakhtin (1996, p.138-139) menciona o tom e estilo dos elogios usados pelos charlatões de feira e vendedores de livros como dominados por superlativos, inflados, não sem ironia ou aleivosia. Os termos usados pelos artistas eram, por exemplo, "mui ilustres", "mui valorosos", "nobres", "grandes" e "inestimáveis". Os superlativos do realismo grotesco predominavam nas propagandas de remédios miraculosos, eram o avesso das grosserias e integravam o discurso brincalhão dos charlatões de feira. O que se percebe nos espetáculos de Chaves é o uso contínuo de formas verbais de tratamento que sugerem uma comparação com a abundância de superlativos utilizada pelos artistas na Idade Média. Entretanto, as expressões verbais "respeitosas" utilizadas por Chaves no tratamento com o público não chegam a ser infladas tal as como da praça pública em Rabelais; as aleivosias são inexistentes, e, em alguns casos, há uma certa ironia nas brincadeiras. 
Diferentemente dos artistas do Largo, que se apresentam ao público vestidos de calça jeans, camiseta e sapatos, roupas normalmente usadas no cotidiano, Feliciano realiza seus espetáculos vestindo-se de forma apropriada à personagem que representa. A maneira como o artista se veste sugere o riso, pois lembra, como ele próprio menciona, a "figura de um moleque safado". Uma camiseta e uma bermuda larga, cujo comprimento vai até os joelhos, o que proporciona um movimento cômico; nos pés, sandálias; na cabeça, um boné com a aba virada para trás.

Feliciano leva às costas uma grande mochila onde guarda os produtos que comercializa no final de sua apresentação. A partir do momento que escolhe um local apropriado para realizar seu espetáculo, coloca a mochila no chão e começa a atuar. Na tentativa de iniciar a formação da "roda", caminha entre as pessoas que transitam pelo local emitindo sons agudos, muito estridentes, com um apito. Os ruídos transmitidos assemelham-se aos gritos de um gato e podem ser ouvidos à longa distância. Dessa maneira, a atenção dos freqüentadores é atraída para o artista e, aos poucos, sua platéia vai crescendo.

Sua forma de interpelação é por meio de brincadeiras jocosas, que envolvem expressões corporais e verbais. Quando direcionadas às mulheres, geralmente seleciona as jovens, magras, vestidas com minissaias, bermudas curtas, vestidos e calças justas ou com roupas esportivas que, de alguma forma, destaquem a silhueta do corpo. O artista passa as mãos pelo seu próprio corpo, como se estivesse explorando a silhueta feminina e comenta: "Tudo isto é teu?" "Este corpinho é teu?" “Ai, se eu pego tudo isto, eu fico louco!” Muitas vezes manda beijos ou quase chega a beijar de fato o rosto das mulheres devido à proximidade.

A maneira de a personagem interpelar algumas mulheres está diretamente relacionada à sua forma de conceber esse espaço. Acredita que grande parte das pessoas que freqüentam o Brique compartilha de idéias comuns sobre o que é ser uma mulher bonita. Assim, o artista observa o público e, a partir de suas percepções sobre ele, seleciona a brincadeira que irá usar para que ela seja verossímil. Com essas brincadeiras, realiza uma sátira de alguns comportamentos das pessoas que freqüientam o Brique; expõe, por meio do escárnio, as mulheres que julga se enquadrarem no padrão de beleza de seus espectadores para, com isso, atrair a atenção do público. ${ }^{20}$

O riso do público revela a graça em ver, gestual e verbalmente, a ridicularização pública. Mais do que isso, o riso do público significa que foi dito o que socialmente é permitido ao pensamento e não expresso verbalmente com tanta liberdade entre pessoas no espaço da rua. E isso por si só libera o riso dos que assistem às brincadeiras. 
Atento aos movimentos do público, ele escolhe o momento em que exista um número suficiente de pessoas para anunciar o início do "show do gato". Esse momento é quando de fato se pronuncia como um artista que dará continuação a seu trabalho realizando o seu show.

O "show do gato" consiste em uma luta de "vida ou morte" entre um homem e um "gato feroz" escondido dentro de um saco. O artista carrega em sua mão um pedaço de taquara, prometendo ao público bater no gato preto que diz estar dentro do saco. A personagem estimula a curiosidade dos que assistem, pois ele deixa entrever apenas o rabo do animal que, preso por uma corda, é seguidamente ameaçado de ser puxado para fora do saco.

No decorrer do espetáculo, desfere violentos golpes no saco de estopa. O forte barulho das batidas é lançado ao ar, e os estridentes gritos do animal, obtidos pelo uso do apito que carrega na boca, ocasiona espanto e risos naqueles que assistem à cena, chamando também a atenção dos que cruzam pelo local. Geralmente o gato responde de forma grotesca às pancadas que recebe, retrucando numa mistura de miados, gritos e fala: "Filha da puta, doeu". Nesse momento, o público, em geral, reage rindo ou demonstrando espanto pelo tipo de linguajar manifestado. As informações sobre a periculosidade do animal são lembradas durante todo o espetáculo, fazendo o público rir: “Ali está o bichinho, um gato perigosíssimo, cabeçudo. Engoliu um menino em São Paulo, cagou um aposentado em Viamão".

É comum, nas apresentações, o uso de expressões grotescas como "cagar", "peidar" e "mijar".

As brincadeiras que se referem ao baixo corporal são predominantes nos espetáculos, como se pode constatar na fala da personagem em uma apresentação em que faz alusão aos órgãos genitais do gato, anunciando a uma mulher, assim como ao público em geral, que se trata de uma gato “perigosíssimo" de duas cabeças:

Agora vai ter sangue, violência, vanerão, rock and roll, heavy metal e muito sexo! (Olhando para uma mulher que está no público, aponta o pedaço de taquara para o animal.) Ali está o gato de duas cabeças, moça bonita. Uma cabeça grande e uma pequena. A pequena é mais perigosa, não tem cérebro. É comandada por controle manual. O remoto, não funciona! A bateria nunca carrega!. 21

\footnotetext{
20 Assim, o "homem do gato" executa brincadeiras envolvendo uma crítica satírica aos costumes tal qual o faziam os bufões quando se apresentavam aos nobres na Idade Média.

${ }^{21}$ Trecho de uma filmagem realizada em novembro de 2000 por Neiva Rosa Garcia.
} 
O enunciado de que o gato é "perigosíssimo" porque tem duas cabeças por si só não provoca o riso porque conduz as pessoas a pensarem que o animal é um gato que nasceu com mais de uma cabeça, por isso ele é perigosíssimo. Mas quando diz: "Uma cabeça grande e uma pequena. A pequena é mais perigosa, não tem cérebro. É comandada por controle manual [...]”, a personagem realiza uma alternância de código, ${ }^{22}$ definindo assim o enquadre ${ }^{23}$ que pretende estabelecer ao público, que é o de uma brincadeira que envolve o baixo corporal. Piadas que mencionam o órgão genital masculino chamando-o de "cabeça sem cérebro" são muito conhecidas, então o artista usa essa informação adaptando-a em seu espetáculo, e as pessoas, por sua vez, ao perceberem a ambivalência presente no enunciado, começam a rir. Normalmente as brincadeiras que mencionam de alguma forma o baixo corporal provocam o riso porque se referem às partes do corpo consideradas proibidas, pelo decoro moral, de serem referidas em público.

Outras vezes, as brincadeiras envolvem expressões grotescas que se referem diretamente ao baixo corporal. Note-se um trecho de um espetáculo em que o artista, para provocar o riso das pessoas, realiza uma brincadeira em que o apito e o baixo corporal estão diretamente envolvidos: ${ }^{24}$

[...] Vejam o apito do gato, se adapta a todas as idades. A senhora para o marido coloca em cima da língua e sopra. Quando sopra com força, cuidado! (O artista coloca as mãos no traseiro.) Mantenha o cu trancado. (O público ri.) Teve uma senhora lá em Torres, no verão, uma argentina não trancou, quando ela soprou, o cu voou. (o artista estende o braço em direção ao céu tentando com isso expressar uma longa distância e as pessoas riem. Em seguida olhando para o alto começa a correr como se estivesse se preparando para pegar algo que a qualquer momento iria cair dizendo) E o povo atrás pega, pega. (Imita uma pessoa olhando para cima e correndo) E o marido desesperado: Não, não. O currículo de minha senhora, não!

No período de verão, Feliciano se apresenta em diversas praias do litoral gaúcho porque considera que grande parte das pessoas da cidade que possuem "poder aquisitivo" vai para esses lugares. De fato, o número de freqüentadores no Brique da Redenção diminui consideravelmente nessa época do ano porque as atividades de lazer programadas envolvem, na maioria das vezes, viagens. Conforme Feliciano: "Eu busco cidades pólos, eu busco quem tem poder aquisitivo por isso viajo para outros lugares".

\footnotetext{
22 A expressão "alternância de código" utilizada aqui é no sentido do conceito de footing de Goffman (1998, p.70): "Footing representa o alinhamento, a postura, a posição, a projeção do 'eu' de um participante na sua relação com o outro, consigo próprio e com o discurso em construção".

23 Goffman (1998,p.57) conceitua enquadre (frame) como: “[...] de natureza psicológica que capta o grau de ambivalência presente nas comunicações, suas funções, bem como relações sutis de subordinação entre as mensagens"
} 
Acreditando que grande parte dos freqüentadores do Brique tem como uma de suas opções de lazer o veraneio no litoral norte do Rio Grande do Sul, Feliciano utiliza-se desse dado, mencionando em seus espetáculos essa forma de lazer praticada pelo grupo social a que julga pertencer o público que freqüenta o Brique, para assim chamar sua atenção. Procura adaptar suas brincadeiras ao perfil de público em relação aos seus valores, gostos e estilo de vida. Como ele diz:

“O ‘show do gato’ se adapta a todo tipo de público.”

\section{7. “Espetáculos de rua”: culturas populares}

Os "espetáculos de rua" analisados neste trabalho refletem, por meio de suas formas de brincar com o público, muito do cotidiano das pessoas, de seus valores, costumes e estilo de vida. No Largo Glênio Peres, os artistas, ao rirem dos envolvidos nas brincadeiras, também riem de si mesmos, de seus gostos e valores. A personagem do Brique da Redenção, de certa forma, também, mas há um aspecto crítico em suas brincadeiras, denunciado pela maneira satírica com que aborda o comportamento social dos que frequientam esse espaço. As características dos "espetáculos de rua" os fazem singulares e estão diretamente relacionadas ao público, ou seja, ao espaço onde são realizados.

Cada espetáculo tem sua forma de fazer que é própria do "artista de rua" que o executa e que é influenciada por sua trajetória especifica como "artista de rua"; são criações que ressaltam particularidades e semelhanças com as "maneiras de fazer" 25 de colegas de profissão. São manifestações culturais que se constituem a partir da bricolage de acontecimentos da vida cotidiana que, transformados, adaptados aos espetáculos, fazem do "artista de rua", conforme Certeau (1994), um “inventor do cotidiano", aquele que o inventa graças à “arte de fazer”, às táticas utilizadas, como uso do boneco Peteleco nos espetáculos de Pedro, das mágicas nas apresentações de Chaves e do gato dentro de um saco nos espetáculos de Feliciano e as formas de falar dos "artistas de rua" em seus eventos.

\footnotetext{
24 Trecho de uma filmagem realizada em novembro de 2000 por Neiva Rosa Garcia .

${ }^{25}$ Expressão utilizada por CERTEAU, Michel de. A invenção do Cotidiano: 1. Artes de fazer. Petrópolis, RJ: Vozes, 1994.
} 
De acordo com Certeau (1994, p.103), sobre as "maneiras de falar": "São manipulações da língua relativas à ocasião e destinadas a seduzir, captar ou inventar a posição lingüistica do destinatário". Nesse sentido, o vocabulário manifesto pelos "artistas de rua" é orientado de acordo com as percepções que têm do público que freqüenta os espetáculos.

O uso de expressões "respeitosas" ou grotescas, que envolvem o baixo corporal, somente pode ser entendido no contexto de cada espetáculo; são "maneiras de falar" adaptadas ao espaço e ao tempo em que ocorrem e que somente situadas nesses eixos podem ser pensadas como táticas usadas nos “espetáculos de rua". Portanto, cada "espetáculo de rua" possui suas táticas, no entanto suas características comuns, aquelas que denunciam que são manifestações de culturas populares, constituem alternativas aos modelos culturais dominantes, tais como as manifestações teatrais realizadas em casas de espetáculo. Uma dessas características é o fato de os artistas construírem os "espetáculos de rua" a partir da observação do espaço em que é executado, ou seja, das pessoas que o freqüentam, transformando o ambiente da rua em palco e os transeuntes, em platéia ativa na construção do evento.

Pode-se dizer que os "espetáculos de rua" têm na subversão das formas dominantes o seu poder de criação, por exemplo, no Largo, os espetáculos ocorrem num espaço que não o de lazer, subvertendo o tempo "oficial" do trabalho; no caso do Brique, o uso do vocabulário predominantemente grotesco e escatológico subverte as formas "oficiais" de linguagem; as apresentações se constroem a partir da interação estabelecida na situação de espetáculo, subvertendo a forma de construção tradicional de teatro em casas de espetáculos. Nesse sentido, os "espetáculos de rua" são subversivos e demonstram resistência cotidiana às formas de trabalhos convencionais, pelo seu caráter alternativo, e às formas de manifestações culturais dominantes à medida que inventam as próprias "maneiras de fazer", o que faz desses "espetáculos de rua" manifestações de culturas populares.

\section{Considerações finais}

O oficio de "artista de rua" possui particularidades e semelhanças em relação às formas de realizar os "espetáculos de rua". 
Uma das características importantes comum aos espetáculos é o local onde ocorrem, regiões de grande fluxo de pessoas. Outra fundamental semelhança é a observação minuciosa que os artistas fazem das pessoas que freqüentam o espaço em que são praticados tais eventos. Os "artistas de rua" observam o público de suas "rodas" para selecionar, em seu repertório, as brincadeiras que serão executadas: consideram as características das pessoas que compõem o público para escolher a brincadeira apropriada de forma que essa seja verossímil. A verossimilhança é a chave dos "espetáculos de rua", pois ela proporciona a aceitação de cada brincadeira, manifesta por meio do riso.

Os "artistas de rua" no Largo e no Brique possuem maneiras distintas de realizar seus espetáculos, que são influenciadas originalmente pelas trajetórias particulares de cada artista. O trabalho em espaços da rua foi a maneira que encontraram, em momentos distintos de suas vidas, para assegurar um meio de subsistência, ou seja, uma forma de trabalho em que é necessário um esforço diário para ganhar, como eles próprios dizem, o "pão de cada dia".

Os caminhos individuais percorridos como "artista de rua" e a influência do espaço nas formas de atuar geram "maneiras de fazer" diferenciadas, que levam a um rico campo de possibilidades de alternativas de lazer a muitos que freqüentam as "rodas" de espetáculos. São culturas populares que, graças à "arte de fazer" de cada artista, oferecem caminhos alternativos a certos modelos dominantes de lazer em nossa sociedade. No Largo Glênio Peres, em particular, os eventos culturais proporcionam momentos de lazer num tempo reservado ao trabalho. Portanto, subvertem o tempo do lazer, aquele do fim de semana, definido pelo tempo do trabalho.

As "maneiras de fazer" dos "artistas de rua" nos espetáculos refletem o quanto são ricas essas manifestações culturais no que diz respeito às formas de interpelar verbalmente o público, ao fato de somente poderem ser entendidas em relação ao espaço e aos momentos de interação vivenciados em cada espetáculo. Nesse sentido, no Largo Glênio Peres há predominância de um vocabulário que enobrece, atribui respeito ao público que participa nas "rodas". É a forma que os artistas encontraram de chamar a atenção do público composto, na maioria das vezes, conforme os artistas, por "pessoas simples", que freqüentam os espetáculos em busca de seus "medicamentos" e de diversão durante a semana. Já no Brique da Redenção, o artista adapta seu espetáculo ao perfil de público que freqüenta o local, pessoas das camadas médias da sociedade. 
As brincadeiras efetuadas envolvem um vocabulário predominantemente grotesco, escatológico, ambivalente, que subverte a forma de linguagem "oficial” esperada nas interações e sugere a aceitação das pessoas pelo seu caráter brincalhão e satírico, levando, de forma cômica, à desnudez comportamental dos que freqüentam o local. Para finalizar este artigo, ressalto que os "espetáculos de rua" no Largo Glênio Peres e no Brique da Redenção refletem diferentes gostos, valores e estilos de vida da sociedade complexa em que vivemos, graças à fundamental característica de subversão e de resistência cotidiana dessas culturas populares manifestas nas ruas da cidade.

\section{REFERENCIAS}

BAKHTIN, Mikhail. A Cultura Popular na Idade Média e no renascimento. São Paulo. HUCITEC, 1996.

BURKE, Peter. A Cultura Popular na Idade Moderna. São Paulo : Companhia das Letras, 1989. CARVALHO, Luciana G. Os “espetáculos de rua” no Largo da Carioca. 1997. Dissertação (Mestrado em Antropologia) Programa de Pós- Graduação em Antropologia, UFRJ, Rio de Janeiro, 1997.

DA MATTA, R. "Espaço, casa, rua e outro mundo: O caso do Brasil". In: A Casa \& Rua. Espaço, Cidadania, mulher e morte no Brasil. São Paulo: Brasiliense, 1997.

CERTEAU, Michel de. A invenção do Cotidiano: 1. Artes de fazer. Petrópolis, RJ: Vozes,1994. DUMAZEDIER, Joffre. Lazer e Cultura Popular. São Paulo: Perspectiva, 1973. Cap.1 e 2.

GOFFMAN, Erving. A Representação do Eu na Vida Cotidiana. Tradução de Maria Célia Santos Raposo. Petrópolis: Vozes, 1989.

GOFFMAN, Erving.. Sociologia Interacional: antropologia, lingüística e sociologia em análise do discurso. Porto Alegre : AGE, 1998.

HUIZINGA, Johan. Homo Ludens. São Paulo : Perspectiva, 1971.

MAGNANI, José Guilherme C. Festa no Pedaço: Cultura Popular e Lazer na Cidade. São Paulo: Brasiliense, 1998.

MAGNANI, José Guilherme C "Unidade e Fragmentação em Sociedades Complexas" In: Projeto e Metamorfose. Antropologia das Sociedades Complexas. Rio de Janeiro : Jorge Zahar, 1994.

Zero Hora, Porto Alegre, p.67, 29 outubro.1998. 